\title{
Do Turkish Obstetricians not Recommend Tetanus Vaccine During Pregnancy?
}

\section{Türkiye'deki Kadın Hastalıkları ve Dog̃um Uzmanları Gebelikte Tetanoz Așısını Önermiyor mu?}

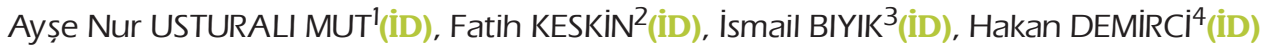 \\ ${ }^{1}$ Department of Public Health, Ankara University Faculty of Medicine, Cebeci Hospital, Ankara, Turkey \\ 2 Clinic of Gynecology and Obstetrics, Edirne Sultan I. Murat State Hospital, Edirne, Turkey \\ ${ }^{3}$ Clinic of Gynecology and Obstetrics, Health Sciences University, Evliya Çelebi Training and Research Hospital, Kütahya, Turkey \\ ${ }^{4}$ Department of Family Medicine, Health Sciences University, Bursa Higher Specialization Training and Research Hospital, \\ Bursa, Turkey
}

\begin{abstract}
Introduction: We evaluated the recommendations of Ob/Gyn specialists or residents about tetanus vaccination during pregnancy, related factors, and the reasons for not recommending vaccination.

Materials and Methods: All active-duty Ob/Gyns in Turkey constitute the universe of this descriptive and cross-sectional study. The stratified sampling method based on geographical area was used to reach the sample group. The final analysis included a total of 393 Ob/Gyns (107.9\% of the target sample size).

Results: Of the participants, $15.8 \%(\mathrm{Cl}=12.1 \%-19.5 \%)$ stated that they did not recommend tetanus vaccination to pregnant women. Of the physicians younger than 30 years, $32.4 \%$ were found to not recommend tetanus vaccination while this rate was $11.3 \%$ among physicians aged between 30-39 years. Among the physicians working at private healthcare facilities, the probability of not recommending tetanus vaccination was 2.467 times that among those working at public institutions. This probability was 3.711 times higher among those at university hospitals compared to those working at public institutions. Of the physicians not recommending tetanus vaccination, 90.3\% did not recommend because pregnant women were to give birth in sterile conditions. Of the physicians recommending tetanus vaccination, $17.5 \%$ stated that more than $10 \%$ of the pregnant women who applied to them rejected vaccination. Most frequently cited reasons for rejecting were the thought of vaccine harming the women or the fetus, vaccine-related news reported in the media, and feeling that vaccination was not necessary.

Conclusion: One-sixth of the Ob/Gyns do not recommend tetanus vaccination to pregnant women. In particular, physicians under the age of 30 and those working in private or university hospitals were often found to not recommend vaccination. For sustained elimination of MNT, physicians should be persuaded that tetanus vaccination should be administered even if pregnant women give birth under sterile conditions, and this subject should be emphasized in medical and residency training.
\end{abstract}

Key Words: Tetanus; Immunization; Pregnant; Obstetrician/gynecologist; Vaccine rejection

Received/Geliș Tarihi: 11/04/2020 - Accepted/Kabul Ediliș Tarihi: 05/05/2020

${ }^{\oplus}$ Copyright 2021 by Flora. Available on-line at www.floradergisi.org. 


\title{
Öz \\ Türkiye'deki Kadın Hastalıkları ve Dog̃um Uzmanları Gebelikte Tetanoz Așısını Önermiyor mu?
}

\author{
Ayșe Nur USTURALI MUT' ${ }^{1}$, Fatih KESKIN²², İsmail BIYIK ${ }^{3}$, Hakan DEMIRCi ${ }^{4}$ \\ ${ }^{1}$ Ankara Üniversitesi Tıp Fakültesi, Cebeci Hastanesi, Halk Sag̃llg̃ı Klinig̃i, Ankara, Türkiye \\ 2 Edirne Sultan I. Murat Devlet Hastanesi, Kadın Hastalıkları ve Dog̃um Klinig̃i, Edirne, Türkiye \\ ${ }^{3}$ Sag̃lık Bilimleri Üniversitesi, Evliya Çelebi Eg̃itim ve Araștırma Hastanesi, Kadın Hastalıkları ve Dog̃um Klinig̃i, Kütahya, Türkiye \\ ${ }^{4}$ Sag̃lık Bilimleri Üniversitesi, Bursa Yüksek İhtisas Eg̃itim ve Araștırma Hastanesi, Aile Hekimlig̃i Anabilim Dalı, Bursa, Türkiye
}

Giriş: Bu çalışmada kadın hastalıkları ve doğum uzmanı ve asistan hekimlerinin gebelikte tetanoz aşısını önerme durumlarını, ilişkili faktörleri ve önermeme nedenlerini değerlendirilmeyi amaçladık.

Materyal ve Metod: Bu tanımlayıcı ve kesitsel çalışmanın evrenini Türkiye'de aktif olarak çalışan kadın hastalıkları ve doğum asistan ve uzman hekimleri oluşturmaktadır. Örneklem grubuna ulaşmada tabakalı örneklem yöntemi kullanılmıştır. Analizlere 393 kadın hastalıkları ve doğum hekimi dahil edilmiştir (Hedef örneklem büyüklüğünün \%107.9'u).

Bulgular: Katılımcıların \%15.8'i gebelere tetanoz aşısını önermediğini ifade etmiştir. 30 yaş altı hekimlerin \%32.4'ü, 30-39 yaş arası hekimlerin ise \%11.3'ü tetanoz aşııını önermemektedir. Özel sağlık kurumunda çalışan hekimlerin, tetanoz aşısını önermeme olasılı̆ı devlet kurumunda çalışanların 2.467 katıdır. Bu olasılık üniversite hastanesinde çalışanlarda devlet kurumunda çalışanlarla karşılaştırıldığında 3.711 kat daha fazladır. Aşıyı önermeyen hekimlerin \%90.3'ü aşıyı gebenin hastanede steril şartlarda doğum yapacak olması nedeniyle önermemektedir. Tetanoz aşısını öneren hekimlerin $\% 17.5^{\prime} i$ ise kendilerine başvuran gebelerin \%10'dan fazlasının aşıyı reddettiğini belirtmiştir. En sık reddetme nedenleri; aşının kendisine ve bebeğine zarar vereceğini düşünme, medyadan duyduğu aşıyla ilgili haberler ve aşının gereksiz olduğunu düşünmedir.

Sonuç: Altı kadın hastalıkları ve doğum hekiminden biri gebelere tetanoz aşııını önermemektedir. Özellikle 30 yaş altı ve özel ya da üniversite hastanesinde çalışan hekimlerin aşııı önermediği saptanmıştır. Eliminasyon başarısının devamlıı̆̆ı için gebeler hastanede ve steril şartlarda doğum yapsa bile tetanoz aşııının önerilmesi gerektiği konusunda hekimler ikna edilmeli ve tıp fakültesi ve asistanlık eğitim sürecinde bu konu vurgulanmalıdır.

Anahtar Kelimeler: Tetanoz; Bağışıklama; Gebe; Kadın hastalıkları ve doğum; Aşı reddi

\section{INTRODUCTION}

Tetanus is an infectious disease with a high mortality rate, which is caused by the toxin of Clostridium tetani. The disease usually emerges as a result of traumas involving the objects that contain $C$. tetani spores and is difficult to eradicate due to the widespread nature of its microbial agent $^{[1]}$.

Tetanus that appears during pregnancy or within 6 weeks of the end of pregnancy is called maternal tetanus. Tetanus that appears within the first 4 weeks after birth is called neonatal tetanus. The infection follows abortion, miscarriages, or unhygienic delivery practices in maternal tetanus; it is usually through the umbilical cord stump in neonatal tetanus ${ }^{[2]}$. Neonatal tetanus is usually fatal; approximately 30.848 neonates have died from neonatal tetanus in 2017 according to the estimates from the World Health Organization $(\mathrm{WHO})^{[1]}$. Protection from neonatal tetanus depends on the transplacental transfer of specific IgG antibodies induced by maternal tetanus immunization ${ }^{[3]}$.

The World Health Organization announced in 2009 that maternal and neonatal tetanus (MNT) had been eliminated in Turkey ${ }^{[4]}$. Only one neonatal tetanus case has been reported in 2014, and no neonatal case has been reported since $2014^{[5]}$.

The vaccination of recorded pregnant women for tetanus is one of the objectives of Turkey's comprehensive immunization program to achieve sustained elimination ${ }^{[6]}$. A nationwide survey in Turkey indicated that $80.6 \%$ of women were vac- 
cinated for tetanus at antenatal visits during their last pregnancies ${ }^{[7]}$. In a study in 2008, $72.3 \%$ of the women aged 15-49 were seropositive for tetanus; the rate was $74.2 \%$ in 2011 and the rate was $90.34 \%$ for pregnant women in 2017 ${ }^{[8-10]}$.

In Turkey, tetanus vaccines are provided for pregnant women free of charge at family health centers. In Turkey, obstetrics and gynecology (Ob/Gyn) specialists do not serve in primary health care facilities, but almost all pregnant women visit an Ob/Gyn specialist during the pregnancy period and declare that their regular prenatal care is provided by an Ob/Gyn specialist ${ }^{[11]}$.

Although healthcare professionals are considered to be the most reliable source of information about vaccination, their own opinions about vaccination influence their decision to recommend vaccination to patients. Likewise, an Ob/Gyn specialist's opinion about vaccination for tetanus during pregnancy may influence whether the pregnant women they follow up would decide to get vaccinated. It has been speculated that some of the Ob/Gyn specialists in Turkey do not recommend tetanus vaccination to pregnant women on the grounds that the delivery would be at sterile conditions in a hospital. Establishing the current situation in Turkey related to the opinions of $\mathrm{Ob} / \mathrm{Gyn}$ specialists about this issue would guide future programs to sustain a high rate of tetanus vaccination during pregnancy.

This study aimed to evaluate the recommendations of $\mathrm{Ob} / \mathrm{Gyn}$ specialists or residents about tetanus vaccination during pregnancy, related factors, and the reasons for not recommending vaccination if they do not recommend.

\section{MATERIALS AND METHODS}

This study is a descriptive and cross-sectional study conducted in accordance with the recommendations of STROBE guidelines ${ }^{[12]}$

All active-duty Ob/Gyn specialists or residents in Turkey constitute the universe of this study. The number of active-duty Ob/Gyn specialists or residents in Turkey is 6.921 as of 15 June 2018, according to the data from the Department of Human Resources at the Ministry of Health. Adequate sample size was calculated to be 364 with Epi Info software, considering a rate of $50 \%$ for Ob/Gyn specialists or residents to recommend tetanus vaccination for pregnant women (dependent variable), a universe of 6.921, a confidence interval of $95 \%$, and a margin of error of $5 \%$. The stratified sampling method was used to reach the sample group. The number of $\mathrm{Ob} / \mathrm{Gyn}$ specialists or residents working in each of the seven geographical regions was obtained from the Ministry of Health, and stratification was done proportional to these numbers. Since there is no list of all Ob/Gyn specialists or residents working in various settings (private practice, clinics, state hospital, university hospital, etc.), a sampling from a list of physicians was not possible. Therefore, the data were collected through a 4300-member restricted-access Facebook group of Ob/Gyn specialists and residents. The link for the survey form was shared between the hours of 18.00-20.00 on Mondays and physicians in this group were invited to participate in the study. The survey forms also recorded the geographical area where the physician worked in order to be able to track participation from various regions. Google forms, used for data collection, recorded the date and time the responders answered the questionnaire. The survey responses were removed from the data set based on the date and time of data collection if the responses disturb the stratification calculated based on the geographical area. When data were missing from certain regions, the survey form continued to be shared in the group, specifically addressing the physicians working in these regions. A total of 412 physicians participated in the survey; 19 of these were removed from the data set for disturbing the stratification. The final analysis included a total of $393 \mathrm{Ob} / \mathrm{Gyn}$ specialists and residents (107.9\% of the target sample size). No missing values were found in the data set. Required and actual sampling from various geographical regions according to stratification is given in Table 1 .

The variables were decided by three Ob/Gyn specialists and a public health specialist through consensus. The dependent variable was the participants' status of recommending tetanus vaccination against MNT for pregnant women who did not have the vaccination, did not remember getting vaccinated, or did not have a vaccination 
Table 1. Required and actual sampling from various geographical regions according to stratification

\begin{tabular}{lcccc} 
& \multicolumn{2}{c}{ Required sampling } & \multicolumn{2}{c}{ Actual sampling } \\
\cline { 2 - 5 } Geographical Regions & $\mathbf{n}$ & $\%$ & $\mathbf{n}$ & $\%$ \\
\hline Marmara & 132 & 36.4 & 143 & 71 \\
Central Anatolia & 66 & 18.1 & 54 & 18.1 \\
Aegean & 50 & 13.8 & 48 & 13.7 \\
Mediterranean & 45 & 12.2 & 31 & 12.2 \\
South-eastern Anatolia & 29 & 7.9 & 26 & 7.9 \\
Black Sea & 24 & 6.6 & 20 & 6.6 \\
Eastern Anatolia & 18 & 5.0 & 393 & 5.1 \\
Total & 364 & 100.0 & & 100.0
\end{tabular}

record. Those who recommended tetanus vaccination were asked about which gestational week they recommended getting the first shot for pregnant women presenting to the clinic in their first trimester, approximately what percentage of pregnant women rejected vaccination, and the most common reason for rejection. Those who did not recommend tetanus vaccination were asked about the reason for not recommending. Independent variables were age, sex, geographic area, academic title, length of service as Ob/Gyn, type of institution, opinion about MNT. The data were collected through an electronic form consisting of 16 questions that were prepared using Google forms. The pilot study of the survey was conducted with $20 \mathrm{Ob} / \mathrm{Gyn}$ specialists or residents, which was included in the study. The data were collected between July 2018 and February 2019.

The data were analyzed using the SPSS Statistical Package ${ }^{\circledR} 21.0$ (SPSS Inc., Chicago, USA). For all statistical analyses, significance level was set at $p<0.05$ with 95\% confidence interval. Descriptive statistics were presented as percentage distribution, mean, standard deviation, minimum, and maximum values. The relationships between dependent and independent variables were analyzed by chi-square test and Fisher-Freeman-Halton test. Bonferroni correction was applied for posthoc analyses. Forward-stepwise logistic regression analysis was used for multivariate analysis of the relationships between the probability of recommending the tetanus vaccine and the independent variables. The independent variables with $p<$ 0.25 in the univariate analyses were included in the logistic regression analysis. There were no multiple linear correlations between the included independent variables.

The local ethics committee of Bursa Yuksek Ihtisas Training and Research Hospital approved the study. The study was therefore performed in accordance with the ethical standards laid down in the 1964 Declaration of Helsinki and its later amendments. All participants gave their informed consent prior to their inclusion in the study.

\section{RESULTS}

Mean age was $40.51 \pm 9.45$ (minimum $=24$, maximum $=67$ ); $59.3 \%$ were females. Of the $\mathrm{Ob} /$ Gyn specialists, $48 \%$ had less than ten years of experience. Of the residents, $68.2 \%$ had more than three years of residency experience. Of the participants, $42.3 \%$ worked in a private hospital, clinic, or practice.

Of the participants, $15.8 \%$ (Confidence Interval-CI=12.1\%-19.5\%) stated that they did not recommend tetanus vaccination to pregnant women. A significant difference was found between physicians younger than 30 years and those aged 30-39 years $(p<0.001)$ or $40-49$ years $(p<$ 0.001) in terms of not recommending tetanus vaccination (Table 2).

Multiple logistic regression analysis indicated that the probability of not recommending tetanus vaccination to pregnant women by the physicians aged 30-39 years was less than $89 \%$, by the physicians aged 40-49 years was less than $86.2 \%$, and by the physicians aged 50-59 years was less than $83.5 \%$ compared to the probability 
Table 2. Variables related to Ob/Gyns' status of recommending tetanus vaccination to pregnant women

\begin{tabular}{|c|c|c|c|c|}
\hline \multicolumn{5}{|c|}{ Recommending tetanus vaccination } \\
\hline & Yes & No & Total & \\
\hline Variable & $\mathrm{n}, \%$ & $\mathrm{n}, \%$ & n, \% & $\mathbf{p}$ \\
\hline \multicolumn{5}{|l|}{ Sex } \\
\hline Female & $199,85.4$ & $34,14.6$ & $233,59.3$ & \multirow{2}{*}{$0.437^{*}$} \\
\hline Male & $132,82.5$ & $28,17.5$ & $160,40.7$ & \\
\hline \multicolumn{5}{|l|}{ Age } \\
\hline$<30$ & $23,67.6$ & $11,32.4$ & $34,8.7$ & \multirow{5}{*}{$0.024^{\dagger}$} \\
\hline $30-39$ & $165,88.7$ & $21,11.3$ & $186,47.3$ & \\
\hline $40-49$ & $78,83.9$ & $15,16.1$ & $93,23.7$ & \\
\hline $50-59$ & $54,83.1$ & $11,16.9$ & $65,16.5$ & \\
\hline$\geq 60$ & $11,73.3$ & $4,26.7$ & $15,3.8$ & \\
\hline \multicolumn{5}{|l|}{ Geographical Region } \\
\hline Marmara & $111,77.6$ & $32,22.4$ & $143,36.4$ & \multirow{7}{*}{$0.085^{\dagger}$} \\
\hline Central Anatolia & $59,83.1$ & $12,16.9$ & $71,18.1$ & \\
\hline Aegean & $45,83.3$ & $9,16.7$ & $54,13.7$ & \\
\hline Mediterranean & $44,91.7$ & $4,8.3$ & $48,12.2$ & \\
\hline Southeastern Anatolia & $29,93.5$ & $2,6.5$ & $31,7.9$ & \\
\hline Black Sea & $24,92.3$ & $2,7.7$ & $26,6.6$ & \\
\hline Eastern Anatolia & $19,95.0$ & $1,5.0$ & $20,5.1$ & \\
\hline \multicolumn{5}{|l|}{ Title } \\
\hline Resident & $31,75.6$ & $10,24.4$ & $41,10.4$ & \multirow{5}{*}{$0.301^{\dagger}$} \\
\hline Specialist & $271,85.5$ & $46,14.5$ & $317,80.7$ & \\
\hline Assistant professor & $11,78.6$ & $3,21.4$ & $14,3.6$ & \\
\hline Associate professor & $12,92.3$ & $1,7.7$ & $13,3.3$ & \\
\hline Professor & $6,75.0$ & $2,25.0$ & $8,2.0$ & \\
\hline \multicolumn{5}{|l|}{ Institution } \\
\hline Public hospital & $96,88.1$ & $13,11.9$ & $109,27.7$ & \multirow{5}{*}{$0.156^{\dagger}$} \\
\hline University hospital & $20,71.4$ & 8, 28.6 & $28,7.1$ & \\
\hline Training and research hospital & $79,87.8$ & $11,12.2$ & $90,22.9$ & \\
\hline Private hospital & $103,83.1$ & $21,16.9$ & $124,31.6$ & \\
\hline Private practice & $30,78.9$ & $8,21.1$ & $42,10.7$ & \\
\hline \multicolumn{5}{|c|}{ Maternal tetanus is a significant health problem in Turkey } \\
\hline Yes & $190,97.4$ & $5,2.6$ & $195,49.6$ & \multirow{2}{*}{$<0.001^{*}$} \\
\hline No & $141,71.2$ & $57,28.8$ & $198,50.4$ & \\
\hline \multicolumn{5}{|c|}{ Neonatal tetanus is a significant health problem in Turkey } \\
\hline Yes & $189,95.5$ & $9,4.5$ & $198,50.4$ & \multirow{2}{*}{$<0.001^{*}$} \\
\hline No & $142,72.8$ & $53,27.2$ & $195,49.6$ & \\
\hline \multicolumn{5}{|c|}{$\begin{array}{l}\text { My decision to recommend tetanus vaccination is affected by the socio-demographic and economic status o } \\
\text { pregnant women }\end{array}$} \\
\hline Yes & $90,72.6$ & $34,27.4$ & $124,31.6$ & \multirow{2}{*}{$<0.001^{*}$} \\
\hline No & $241,89.6$ & $28,10.4$ & $269,68.4$ & \\
\hline \multicolumn{5}{|c|}{ Tetanus vaccination for pregnant women is administered at my institution } \\
\hline Yes & $41,95.3$ & $2,4.7$ & $43,10.9$ & \multirow{3}{*}{$0.034^{*}$} \\
\hline No & $290,82.8$ & $60,17.2$ & $350,89.1$ & \\
\hline Total & $331,84.2$ & $62,15.8$ & $393,100.0$ & \\
\hline
\end{tabular}


by the physicians aged below 30 years. Among the physicians working at private healthcare facilities, the probability of not recommending tetanus vaccination was 2.467 times that among those working at public institutions. This probability was 3.711 times higher among those at university hospitals compared to those working at public institutions. Physicians who did not consider neonatal tetanus as a significant health problem in Turkey were 8.808 times more likely to not recommend tetanus vaccination. Among those who stated that their decision to recommend tetanus vaccination was not influenced by the socio-demographic and economic status of the pregnant women, the probability of not recommending tetanus vaccination was less than $73.5 \%$ than those stated otherwise. The probability of not recommending tetanus vaccination was 9.108 times higher among physicians who work at an institution where the tetanus vaccination for pregnant women was not administered on site (Table 3).

The physicians who reported recommending tetanus vaccination $(n=331)$ were asked at which week of pregnancy they recommended the vaccine to be administered; $91.4 \%$ recommended at the second trimester, 50.1\% recommended at the $20^{\text {th }}$ week of pregnancy.

Figure 1 shows the reasons stated by 62 physicians for not recommending tetanus vaccination for pregnant women. Of these physicians, 90.3\% did not recommend because pregnant women were to give birth in sterile conditions at a hospital, 25.8\% suggested that there was no risk of MNT in Turkey (Figure 1).

Of the physicians who reported recommending tetanus vaccination, $40.5 \%$ stated that they had never come across a pregnant woman rejecting the vaccination, $17.5 \%$ stated that more than $10 \%$ of the pregnant women who applied to them rejected vaccination. Most frequently cited reasons for rejecting tetanus vaccination are given in Figure 2.

The physicians were asked about the measures that might be important in preventing MNT; $58.3 \%$ of the physicians proposed promoting tetanus vaccinations to include all pregnant women, $55.2 \%$ suggested promoting delivery in ste-

Table 3. Logistic regression model indicating that the probability of not recommending tetanus vaccination to pregnant women by the physicians

\begin{tabular}{|c|c|c|c|}
\hline Variables in the model & Odds Ratio & \%95 Confidence Interval & $p^{*}$ \\
\hline $\begin{array}{l}\text { Age } \\
\qquad \begin{array}{l}<30 \\
\quad 30-39 \\
40-49 \\
\quad 50-59 \\
\quad \geq 60\end{array}\end{array}$ & $\begin{array}{c}\text { Reference } \\
0.110 \\
0.138 \\
0.165 \\
0.325\end{array}$ & $\begin{array}{l}0.039-0.313 \\
0.044-0.433 \\
0.045-0.601 \\
0.065-1.617\end{array}$ & $\begin{array}{c}<0.001 \\
0.001 \\
0.006 \\
0.170\end{array}$ \\
\hline $\begin{array}{l}\text { Institution } \\
\text { Public institution } \\
\text { Private healthcare facilities } \\
\text { University hospital }\end{array}$ & $\begin{array}{l}\text { Reference } \\
2.467 \\
3.711\end{array}$ & $\begin{array}{c}1.152-5.284 \\
1.196-11.511\end{array}$ & $\begin{array}{l}0.020 \\
0.023\end{array}$ \\
\hline $\begin{array}{l}\text { Neonatal tetanus is a significa } \\
\text { Yes } \\
\text { No }\end{array}$ & $\begin{array}{l}\text { h problem in } \\
\text { Reference } \\
8.808\end{array}$ & $3.992-19.433$ & $<0.001$ \\
\hline
\end{tabular}

My decision to recommend tetanus vaccination is affected by the socio-demographic and economic status of pregnant women

Yes Reference

No $\quad 0.265$

$0.140-0.503$

$<0.001$

Tetanus vaccination for pregnant women is administered at my institution

Yes Reference

$\begin{array}{lccc}\text { No } & 9.108 & \mathbf{1 . 4 6 9 - 1 6 . 4 8 4} & \mathbf{0 . 0 1 8}\end{array}$

* Multiple Logistic Regression Analysis-Forward method $p$ value. 


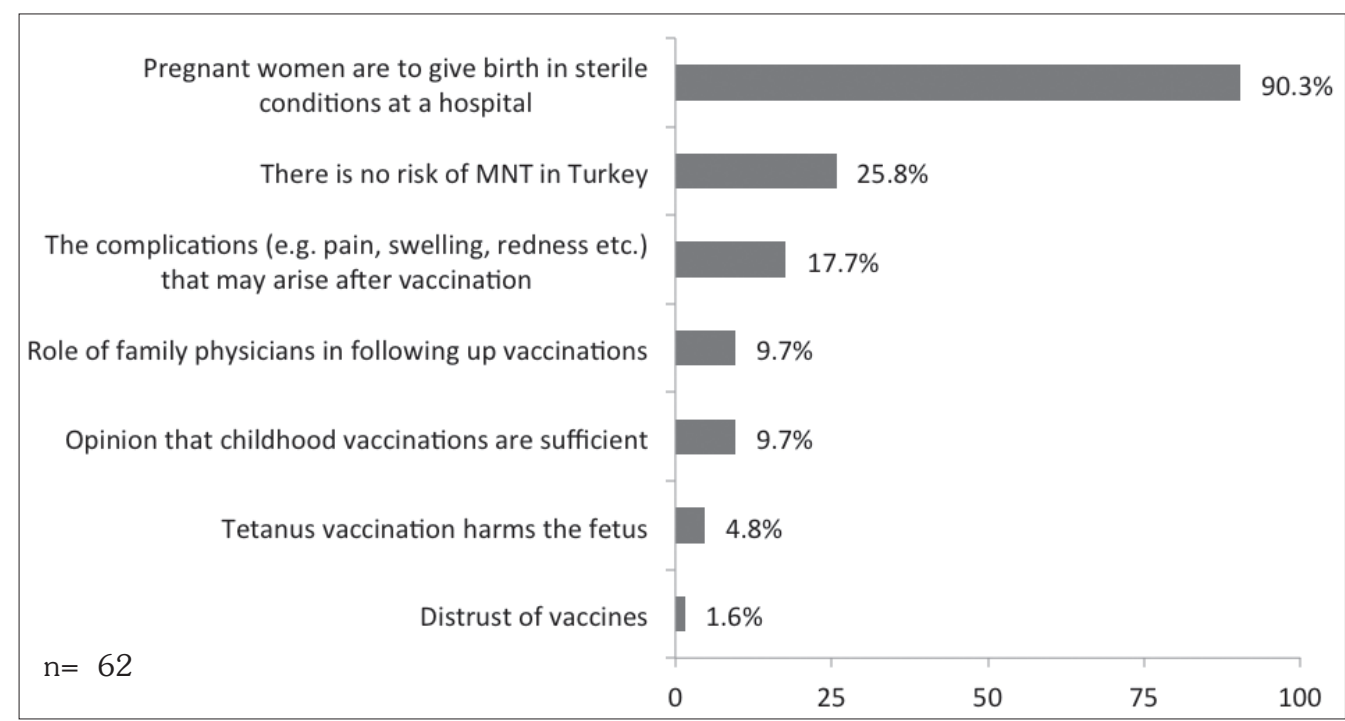

Figure 1. The reasons stated by 62 physicians for not recommending tetanus vaccination for pregnant women.

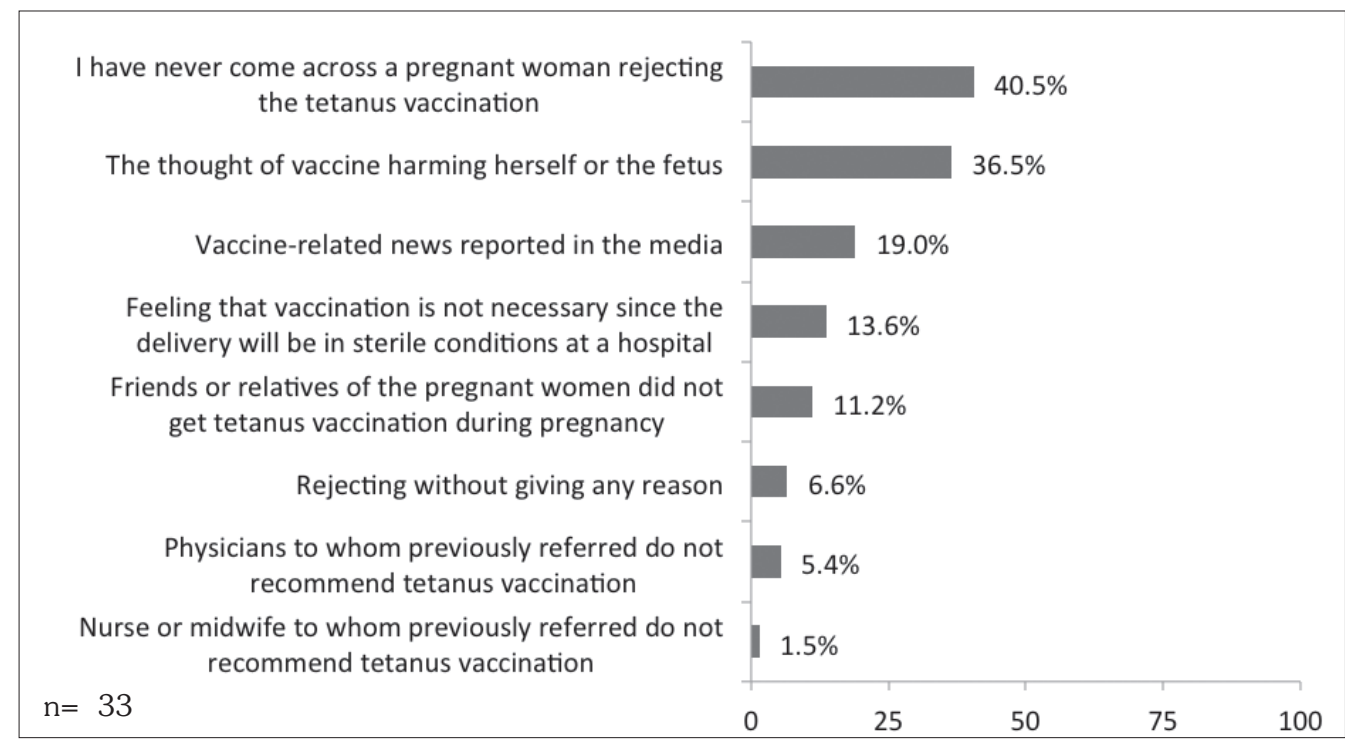

Figure 2. The most frequently cited reasons for rejecting tetanus vaccination by pregnant women, according to physicians who reported recommending tetanus vaccination.

rile conditions at hospitals, 50.1\% recommended improving family health centers' prenatal care services, $41.7 \%$ suggested having the deliveries attended by trained healthcare personnel, $40 \%$ recommended tetanus immunization campaigns to vaccinate all women of fertility age (15-49) living in high-risk areas, $36.6 \%$ recommended the prevention of giving birth at home, and $30 \%$ recommended home visits by healthcare personnel in the first few days after birth to inform family about the care of newborn.

\section{DISCUSSION}

This nationwide online survey showed that about one in six Ob/Gyns in Turkey reported not recommending tetanus vaccination to pregnant women. The decision to not recommend tetanus vaccination was related to variables such as the physician's age, institution, consideration of neonatal tetanus as a significant health problem in Turkey, consideration of the expectant's socio-demographic and economic status, and the 
availability of tetanus vaccination at the healthcare institution at which the physician worked.

The only way to maintain tetanus elimination is vaccination. Pregnant women who have not been vaccinated before should be given at least two doses of vaccine ${ }^{[6]}$. Studies showed that the most significant factor that influences women's decision to get vaccinated during pregnancy was a doctor's recommendation ${ }^{[13-16]}$. Thus, the physician's rate of not recommending tetanus vaccination to pregnant women (15.8\%) in Turkey was not an inadmissible level. But this rate was considerably higher than that in the US $(8 \%)^{[17]}$.

It was found that almost all of the Ob/Gyns in this study followed the pregnancy vaccination schedule outlined by the immunization programs and recommended tetanus vaccination in the second trimester ${ }^{[6]}$.

In Turkey, the number of neonatal tetanus cases was 67 in the year 1990 and 26 in the year $2000^{[5]}$. The necessity of tetanus vaccination during pregnancy may have been emphasized more during the medical training due to the higher incidence of neonatal tetanus in these periods, which resulted in expectedly higher awareness of neonatal tetanus among physicians of older age. Most of the physicians under the age of 30 were residents; one-fourth of Ob/Gyn residents were found to not recommend tetanus vaccination. $\mathrm{Ob} / \mathrm{G} y n$ residents in training are the $\mathrm{Ob} / \mathrm{Gyn}$ specialists of the future and constitute a core group for increasing the awareness about pregnancy tetanus vaccination. In addition to residents, assistant professors and professors need further incentives.

A study covering the period of 2008-2013 found that $7.6 \%$ of births in the eastern part of Turkey (Southeastern and Eastern Anatolia) were not attended by a healthcare worker compared to $0.2 \%$ in the western part of the country (Marmara and Aegean) ${ }^{[7]}$. Higher rates of recommending tetanus vaccination by physicians in the eastern part of the country might be due to the higher probability of giving birth in the absence of healthcare personnel in the region. A study investigating the neonatal tetanus cases in a province in eastern Turkey found that all of the infants involved were delivered at home $e^{[18]}$. A survey in the western part of the country (Marmara Region) found that $86.9 \%$ of women who gave birth at home received the first prenatal care from the obstetrician ${ }^{[19]}$. It is of great importance that all Ob/Gyns recommend tetanus vaccination to pregnant women regardless of the region so that the opportunities for vaccination would not be missed.

In 2007 , a study found that $1.3 \%$ of the $\mathrm{Ob} /$ Gyn specialists working at a private clinic in the western part of the country did not recommend tetanus vaccination to pregnant women ${ }^{[20]}$. The current study found that the physicians working in private clinics were more likely to not recommend vaccination than the physicians at public hospitals. Similarly, a study in the US found that $86 \%$ of the Ob/Gyns not recommending tetanus or influenza vaccine during pregnancy worked at private clinics ${ }^{[17]}$. Physicians working at university hospitals were also more likely to not recommend tetanus vaccination compared to those working at public hospitals. These findings could also be influenced by the disparity between the socio-demographic and economic characteristics of pregnant women who were followed up at public hospitals and those followed up at private or university hospitals.

Approximately half of the physicians in this study considered MNT as an important health problem. A previous study in Turkey found this rate to be $54.7 \%$ in $2013^{[20]}$. Expectedly, those who considered MNT as an important health problem were more likely to recommend tetanus vaccination.

Another factor that influences the decision of the physician to recommend tetanus vaccination was the socio-demographic and economic status of the expectant. In view of that, physicians may be more prudent and recommend tetanus vaccine more frequently to pregnant women of disadvantaged socio-demographic and economic background, considering that they carry a higher risk. The findings by Maral et al. ${ }^{[21]}$ and Erbaydar ${ }^{[22]}$ that pregnant women living in rural areas and homemakers had a higher rate of tetanus vaccination are in support of our findings. As expected, physicians were less likely to recommend 
tetanus vaccination if tetanus vaccination was not administered at their institution. This may be because the physicians who recommended vaccination were more aware of the fact that tetanus vaccination was administered at their institutions.

The risk of neonatal tetanus is not limited to the delivery room. Although an unvaccinated pregnant woman delivers in a hospital with sterile equipment, neonatal tetanus may develop due to a substance that comes in contact with the umbilical cord later ${ }^{[23]}$. Furthermore, the timely administration of maternal vaccination provides both maternal immunity and neonatal passive immunity $^{[3]}$. None of the reasons for not recommending vaccination are based on scientific evidence. Although MNT was eliminated in Turkey, the risk of MNT cannot be ruled out as $C$. tetani is always present in nature ${ }^{[2]}$. Moreover, sustaining the elimination of MNT depends on a high rate of vaccination. The increased role of family physicians in following up vaccinations should not curtail the role of the Ob/Gyns in promoting vaccinations. That pregnant women receive consistent information about tetanus vaccination from the family physician and the Ob/ Gyn specialist would increase their likelihood of getting immunized.

In a study in the US, $32 \%$ of the Ob/Gyns have reported that more than $10 \%$ of pregnant women rejected tetanus vaccination ${ }^{[24]}$. Similar to other studies in the literature, the participants reported the safety concerns about vaccines to be the most common reason for rejection ${ }^{[13,24,25]}$. However, tetanus vaccine has been shown to have a well-tolerated safety profile during pregnancy ${ }^{[26]}$. Pregnant women's decision to get vaccinated is generally influenced by the media, friends, relatives, and the healthcare workers previously attended. In the face of intensified anti-vaccination agenda, the attitudes of the health workers, who are the most reliable source of information about vaccines, are extremely important and decisive. It has been shown that interventions to overcome healthcare workers' incorrect beliefs about vaccination increased vaccination rates ${ }^{[27]}$.

Physicians' opinion about the prevention of MNT was also intriguing. Since a great majority of the pregnant women in Turkey give birth at hospitals and almost half of the participants did not consider MNT to be a significant problem in Turkey, they might have assumed that MNT has already been prevented and that there was no need for further efforts ${ }^{[7]}$

This study which used a nationwide stratified sampling has some limitations. Firstly, data collection was limited to Ob/Gyns who were members of a restricted-access Facebook group since it was not possible to obtain a list and contact information of all Ob/Gyns in the country. Therefore, the generalizability of the results to the greater community of $\mathrm{Ob} / \mathrm{Gyns}$ in the country may be limited. However, the Facebook group used in the study has 4.300 members. The use of social media is fairly high among physicians in Turkey, and physicians of all ages and specialties participate in professional Facebook groups created for their areas of medicine. Therefore, the probability of physicians in this group to recommend tetanus vaccination to pregnant women was not considered to be significantly different from those who are not members.

Secondly, physicians who do not recommend tetanus vaccination to pregnant women might have preferred to not participate in the study and therefore, selection bias might have been inadvertently introduced. Accordingly, the rate of not recommending tetanus vaccination to pregnant women might be underestimated. In addition, the reasons for the rejection of vaccination by pregnant women cited here are limited to those perceived by the physicians. There is a need for studies that address this issue from the perspective of pregnant women.

Despite these limitations, the study is significant in providing prevalence data about Ob/ Gyns' attitude towards tetanus vaccinations in pregnant women, illuminating associated factors, and revealing the physicians' reasons for not recommending the vaccination. Thus, the study may contribute to the policy-making processes related to the subject.

\section{CONCLUSION}

Almost half of the Ob/Gyns were found to not consider MNT as an important health problem in Turkey. Furthermore, one-sixth of the 
$\mathrm{Ob} /$ Gyns reported that they did not recommend tetanus vaccination to pregnant women. In particular, physicians under the age of 30 and those working in the private or university hospitals were often found to not recommend vaccination. For sustained elimination of MNT, physicians should be persuaded that tetanus vaccination should be administered even if pregnant women give birth under sterile conditions in hospitals, and this subject should be emphasized in medical and residency training. Despite birth under sterile conditions in hospitals, the timely administration of maternal vaccination is extremely important in terms of not only maternal immunity but also neonatal passive immunity. Any pregnant woman who rejected tetanus vaccination despite the recommendations should be provided with a clear explanation that the vaccine would not pose any risk for her or the fetus. Training of health workers and improving availability of tetanus vaccines may be opportunities for improving vaccination rates.

\section{ETHICS COMMITTEE APPROVAL}

The approval for this study was obtained from Bursa Higher Specialization Training and Research Hospital Ethics Committee (Decision no: 2011 KAEK 25/2019/01-02, Date: 16.01.2019).

\section{CONFLICT of INTEREST}

The authors declare that they have no conflict of interest.

\section{AUTHORSHIP CONTRIBUTIONS}

Concept and Design: ANUM, FK

Analysis/Interpretation: ANUM, FK

Data Acquisition: ANUM, FK, IB

Writing: ANUM, FK, İB, HD

Revision and Correction: ANUM, FK, İB, HD

Final Approval: ANUM, FK, İB, HD

\section{REFERENCES}

1. World Health Organization (WHO). Immunization, Vaccines and Biologicals. Tetanus. Available from: https://www. who.int/immunization/diseases/tetanus/en/ Accessed date: 20 March 2020.

2. Thwaites CL, Beeching NJ, Newton CR. Maternal and neonatal tetanus. Lancet 2015;385.9965:362-70.
3. Committee on Obstetric Practice, Immunization and Emerging Infections Expert Work Group. Committee Opinion No. 718: Update on immunization and pregnancy: tetanus, diphtheria, and pertussis vaccination. Obstet Gynecol 2017;130(3):e153-e7.

4. World Health Organization (WHO). Weekly epidemiological record, validation of elimination of neonatal tetanus in Turkey by lot quality assurance cluster sampling, No.17, 2009;84:141-8. Available from: https://apps.who.int/iris/ bitstream/handle/10665/241323/WER8417_141-146. PDF? sequence $=1$ \&isAllowed $=y$ Accessed date: 20 March 2020.

5. World Health Organization (WHO). WHO vaccine-preventable diseases: monitoring system. 2019 global summary. Available from: http://apps.who.int/immunization_monitoring/global summary/countries?countrycriteria\%5Bcountry\%5D\%5B\%5D=TUR\&commit=OK;2019 Accessed date: 01 December 2019.

6. T.C. Sağlık Bakanlığı. Temel Sağlık Hizmetleri Genel Müdürlüğü. Genişletilmiş Bağışıklama Programı Genelgesi, 25.02.2008;6111;2008/14. Available from: https://dosyasb.saglik.gov.tr/Eklenti/1117,gbpgenelge2008pdf.pdf?0 Accessed date: 20 March 2020.

7. Hacettepe University Institute of Population Studies. 2013 Turkey Demographic and Health Survey, 2014. Available from: http://www.hips.hacettepe.edu.tr/eng/tdhs13/report/ TDHS_2013_main.report.pdf Accessed date: 20 March 2020.

8. Öner S, Buğdaycı R, Kurt AO, Öztürk C, Şaşmaz T. Tetanus seroprevalence among women 15-49 years old, in Mersin, Turkey. Turkiye Klinikleri J Med Sci 2008;28.6:839-46.

9. Ceylan A, Çöplü N, Saka G, Gül K, Sönmez C, Esen B, ve ark. Diyarbakır Ben-u Sen Sağlık Ocă̆ı Bölgesindeki gebelerde tetanoz seroprevalansI. TAF Prev Med Bull 2011;10(4):481-6.

10. Kader C, Kara M, Gocmen AY, Erbay A, Polat MF. Antibodies against vaccine preventable diseases in pregnant women measles, mumps, rubella, varicella and tetanus in Yozgat, Turkey. Konuralp Medical Journal 201 7;9(2):29-34.

11. Yücel U, Çiçeklioğlu M, Öcek ZA, Taner Ş. Prenatal care utilization level of pregnant women living in three different neighborhoods of Izmir's Bornova district. TAF Prev Med Bull 2015; 14(5):370-7.

12. Von Elm E, Altman DG, Egger M, Pocock SJ, Gotzsche PC, Vandenbroucke JP. The Strengthening the Reporting of $\mathrm{Ob}$ servational Studies in Epidemiology (STROBE) statement: guidelines for reporting observational studies. I Clin Epidemiol 2018;61(4):344-9.

13. Celikel A, Ustunsoz A, Guvenc G. Determination of vaccination status of pregnant women during pregnancy and the affecting factors. J Clin Nurs 2014;23:2142-50.

14. Centers for Disease Control and Prevention. Pregnant Women and Tdap Vaccination, Internet Panel Survey, United States, April 2017. Available from: https://www.cdc.gov/vaccines/imzmanagers/coverage/adultvaxview/pubs-resources/ tdap-report-2017.html. Accessed date: 20 January 2020. 
15. Healy CM, Rench MA, Montesinos DP, Ng N, Swaim LS Knowledge and attitudes of pregnant women and their providers towards recommendations for immunization during pregnancy. Vaccine 2015;33(41):5445-51.

16. MacDougall DM, Halperin BA, Langley JM, McNeil SA, MacKinnon-Cameron D, Li L, et al. Knowledge, attitudes, beliefs, and behaviors of pregnant women approached to participate in a Tdap maternal immunization randomized, controlled trial. Hum Vaccin Immunother 2016;12(4):879. 85.

17. O'Leary ST, Riley $L E$, Lindley $M C$, Allison MA, Crane $L A$, Hurley $L P$, et al. Immunization practices of US obstetrician/gynecologists for pregnant patients. Am J Prev Med 2018;54(2):205-13.

18. Dikici B, Uzun H, Yilmaz-Keskin E, Tas T, Gunes A, Kocamaz $H$, et al. Neonatal tetanus in Turkey; what has changed in the last decade?. BMC Infect Dis 2008;(8)1:112.

19. Oner C, Catak B. The frequency and content of prenatal care determine birth place: a community based case-control study. Iran J Public Health 2019;48(1):120-5.

20. Isaoğlu i, Özsoy SA, Öztürk Dönmez R. Kadın hastalıkları ve doğum uzmanı hekimlerin gebelikte tetanos aşısına ilişkin görüşleri. Ege Tıp Dergisi 2013;52(2):67-72.

21. Maral I, Baykan Z, Aksakal FN, Kayikcioglu F, Bumin MA. Tetanus immunization in pregnant women: evaluation of maternal tetanus vaccination status and factors affecting rate of vaccination coverage. Public Health 2001;115(5):359-64.

22. Erbaydar T. Utilization of prenatal care in poorer and wealthier urban neighbourhoods in Turkey. Eur J Public Health 2003;13(4):320-6.
23. Immunization Action Coalition. Unprotected People \#7 Tetanus, Montana newborn of an unvaccinated mother contracts neonatal tetanus after application of nonsterile clay to the umbilical cord. Available from: http://www. immunize.org/reports/report007.pdf. Accessed date: 20 January 2020.

24. O'leary ST, Riley LE, Lindley MC, Allison MA, Albert AP, Fisher $A$, et al. Obstetrician-gynecologists' strategies to address vaccine refusal among pregnant Women. Obstet Gynecol 2019;133(1):40-7.

25. Kahn KE, Black CL, Ding H, Williams WW, Lu PJ, Fiebelkorn $A P$, et al. Influenza and Tdap vaccination coverage among pregnant women-United States, April 2018. MMWR Morb Mortal Wkly Rep 2018;67:1055-9.

26. Park HJ, Kim SJ, Song R, Chen J, Kim JH, Devadiga R, et al. A 6-year prospective, observational, multi-center post-marketing surveillance of the safety of tetanus toxoid, reduced diphtheria toxoid, and acellular pertussis (Tdap) vaccine in Korea. J Korean Med Sci 2019;34(12):e105.

27. Vouking MZ, Tadenfok CN, Ekani JME. Strategies to increase immunization coverage of tetanus vaccine among women in Sub-Saharan Africa: A systematic review. Pan Afr Med J 2017;27(Supp/3):25

\section{Address for Correspondence/Yazıșma Adresi}

Uzm. Dr. Ayșe Nur USTURALI MUT

Ankara Üniversitesi Tıp Fakültesi Cebeci Hastanesi, Halk Sağlığı Kliniği,

Ankara-Türkiye

E-mail: aysenurusturali@gmail.com 